\title{
„Asszonyunk, Mária megkoronázza Szent Margit asszonyt...”1 Túlélhette-e viharos történelmünket a domonkos apácának, Árpád-házi Szent Margitnak a pozsonyi klarisszáknál őrzött koponyaereklyéje?
}

\author{
Soós Sándor ${ }^{\mathrm{a}} \&$ Soósné Dr. Veres Rózsa ${ }^{\mathrm{b}}$ \\ ${ }^{a}$ Keresztény Múzeum, 2500 Esztergom, Mindszenty tér 2. \\ ${ }^{\mathrm{b}}$ Ferences Gimnázium, 2000 Szentendre, Áprily Lajos tér 2. \\ soos@t-online.hu
}

Soós S. \& Soósné Veres R. (2019): „Asszonyunk, Mária megkoronázza Szent Margit asszonyt...” - Túlélhette-e viharos történelmünket a domonkos apácának, Árpád-házi Szent Margitnak a pozsonyi klarisszáknál örzött koponyaereklyéje? Acta Pintériana, 5: 5-20.

2020. január 18-án lesz 750. évfordulója, hogy a szent életü domonkos apáca, Margit a Nyulak szigetén elhunyt. Életszentségével, szentté avatásának eseményeivel, legendáival, kultuszával sokan foglalkoztak. Jelen írásunkban egyetlen szempontból követjük végig a hozzá füződő eseményeket: mi történt Margitnak a domonkos, majd klarissza nővérek által féltve őrzött ereklyéivel, föleg a koponyaereklyéjével?

A királylány hányatott sorsú ereklyéiről az utolsó, biztosnak látszó, hivatalos jegyzőkönyvben szereplő adat 1789. április 11-ről származik. A rendek feloszlatása után a II. József-féle felvilágosodás következetesen pusztította keresztény örökségünk kincseit. A klarisszáktól 1782-ben lefoglalt ereklyéket a budavári ferences zárdában halmozták fel. Ezek sorsáról II. József úgy intézkedett, hogy azokat nem szabad elárverezni, hanem az értékes tartókból kiszedve oda kell adni egyházi személyeknek vagy szerzetesrendeknek. Ami megmaradt, azt 1789. április 11-én elhamvasztották. A hivatalos lista szerint erre a sorsra jutott Szent Margit koponyája is.

Az apácamunkák hazai történetét feldolgozó könyv előmunkálatai során tünt fel, hogy az Esztergomi Főszékesegyház téli kápolnája ereklyéket, illetve polion díszítéssel ellátott ereklyés apácamunkákat öriz. Ezek között található egy üvegezett, ereklyetartónak minősíthető doboz (1. kép). Ebben a négyszögletes, sötétbarna fadobozban bordó színü, széles ezüstszegélyes párnán selyembe burkolt koponya látható. ${ }^{2}$ Az ezüstszálas szegély régebbi lehet a párnánál. A felvételen úgy látszik,

\footnotetext{
${ }^{1}$ BAROS 1938. 99.

${ }^{2}$ Soós 2006. 11. számú fotó. Esztergomi ismerősök szerint a koponya akár Szent Margit ereklyéje is lehet, amit régen szerzetesnővérek hozhattak a magyar katolikusság központjába. A téli kápolnába állítólag Lékai László bíboros úr hagyatékából került, ő a saját szobájában őrizte. Ezt megerősítő dokumentumok 2006-ban nem álltak rendelkezésre. Az egyházi levéltárak anyagának feldolgozása jelenleg is folyamatban van. A néprajzkutató és az irodalomtörténész számára azonban a szóbeli közlések is jelentős értéküek. Mindkét tudományterület számára alapvető forrásértéket jelentenek a kollektív emlékezetben őrzött és továbbadott információk, még abban az esetben is, ha azok néha látszólag ellentmondó részleteket tartalmaznak. A lényeg, hogy ilyen esetekben minden adatot közölni szükséges. A ma már szigorú személyiségjogi védelem lehetőséget biztosít az adatközlő számára, hogy inkognitóját megőrizze, ezért nem áll módunkban a személyeket megnevezni. Ugyanakkor le kell szögeznünk, hogy megfellebbezhetetlen történeti bizonyítékokat csak pontos, konkrét források írott szövegei biztosíthatnak, de ezek nem állnak rendelkezésünkre. Tehát pusztán a felékesített koponya láttán felvetődött kérdés megvizsgálására törekszünk, ugyanis a szóbeli közlések tökéletesen alkalmasak voltak érdeklődésünk felkeltésére.
} 
hogy az egész ereklyét eredetileg aranyozott ezüstszállal hímezték ki, de az aranyozás szinte mindenhol lekopott, s már csak egy helyen van nyoma.

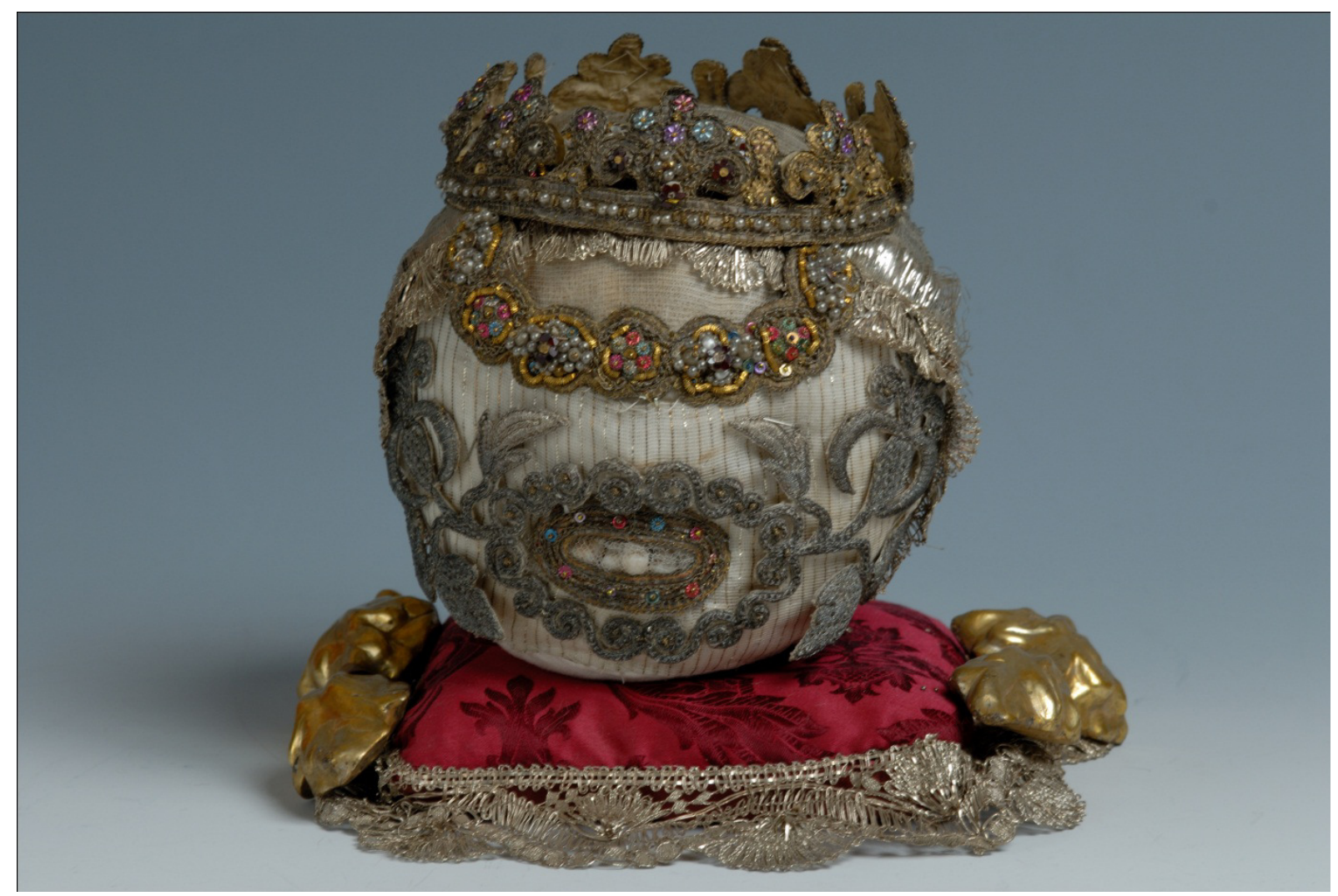

1. kép. Apácamunkával ékesített, feltételezett koponyaereklye. Díszítése: 18. sz. vége-19. sz. közepe. Leltári szám: Bazilika Gyarapodási Napló 21/2006, Esztergomi Bazilika. Fotó: Mudrák Attila, 2006.

A szemet, a homlokot, a szájat és az arc formáját a nehéz hímzés teszi hangsúlyossá. Elöl a korona alatt, a homlokon lefelé kör alakban tizenkét, egymásba érö kerek, vastag, egyenként is kör alakú, flitteres, gyöngyberakásos hímzés, a szem vonalát és a homlokot jelzi. Ebből hatban föleg gyöngyös, hatban föleg virágos-flitteres díszítés található. A két szem helyén lévő kerek díszítményben gyöngyöket találunk, a szemgolyók helyén barna, apró kövek. A haj formáját a kirojtozott selyemszálak mutatják.

A száj körül - annak formáját jelző - kettős ovális körben ezüstszálas hímzés, amelyből a fogak kilátszanak. A fogakat finom háló védi a kieséstől. A belső kör keskenyebb, apró, színes flitterekkel kirakott. A szélesebb ovális díszítéstől két oldalon, a száj szélétől egy-egy tőről indulva, három irányba indás-leveles hímzés halad az orr, a fül és a nyak felé. A koponyát hátul egyszínü, szélesebb ezüstszálakból varrt takaró borítja, az arcot pedig fehér selyem, aranycsíkozású anyag óvja.

A koponya tetejét gyöngyökből készült liliomos, korona alakú fejdísz ${ }^{3}$ ékesíti. A korona alapját megfelelő formára és méretre vágott, finom szőttes anyagból készítették. Ezt díszítették fel. A kör

\footnotetext{
3 A korona=koszorú, égi és földi méltóságok uralkodói jelvénye. SEIBERT 1986. 179. A korona, a diadém már önmagában is az Istentől származó hatalmat jelképezi és egyben rangjelző szerepet tölt be. A liliomos korona a magyar Anjou királyok heraldikai szimbóluma. A liliom a kegyelmet fejezi ki, s gyakran a szűz szentek attribútuma. Ilyen volt Margit királylány is. PÁL \& ÚJVÁRI 1997. 307. Mint motívum elsősorban Szüz Mária ábrázolásain szerepel, de a Keresztény Múzeum 1500 körül készült, színezett fametszete az egyik első, kiemelkedő értékü ábrázolása Margitnak. Ezen a szent kezében liliomot tart, lábánál jobbra lent koronás címerpajzs. CSÉPFALVAY \& KONTSEK 2000. 133. valamint HOPPÁL et al. 1996. 144.
} 
alakú pánt közepén körbe, egy sorba, egy szálra sürủn füzött gyöngyöket erősítettek fel. A szálat a gyöngyök között két-két öltéssel a koronához varrták. A pántból felfelé hét nagyobb, liliomos, s ezek között hét kisebb, csúcsos díszítés emelkedik ki. Közepükön nagyobb gyöngyök, a széleken színes, virágot formáló flitterek. A koronát aranyozott ezüstszálakkal varrták ki, de az aranyozás jórészt itt is lekopott. Felirat nem található rajta.

Hogy e leírásnak a jelentőségét megértsük - az eredeti kutatásunk célját is követve, az apácamunkákra vonatkozó adatokat szem előtt tartva ${ }^{4}$ - vissza kell tekintenünk a magyar középkor évszázadaiba. ${ }^{5}$

A következő kérdésekre keressük a válaszokat. Lehet-e a Szent Margit koponyájára vonatkozó szóbeszédnek bizonyítható, történeti alapja? ? $^{6}$ Túlélhette-e a szent koponyaereklyéje a történelem nehéz időszakait? Lehet, hogy az ereklye hitelességének bizonyításához csak a legkorszerübb összehasonlító természettudományos vizsgálatokra lenne szükség? ${ }^{7}$ Mit igazolnak a legújabb levéltári kutatások? Legyen bárhogy is, de a szent lehetséges ereklyéjére vonatkozó történeti vizsgálódás mindenképpen megér egy eszmefuttatást.

1270. január 18-án, vasárnapra virradóra halt meg a Nyulak szigetén Margit királylány, ${ }^{8}$ akinek legendájában találhatjuk az első utalást Magyarországon a kolostori kézimunkázásra. ${ }^{9}$ Életéről, a számára épített zárdáról aránylag sokat tudunk. ${ }^{10}$

A magyar királyi, főnemesi, nemesi otthonokból zárdába vonuló lányok a mély hitük mellett az igényes kézimunka-szeretetet vitték magukkal. Így volt ez már a középkorban is. A szent életủ Margit királyleányról olvashatjuk a róla készült legendában:

„Ebednek vtanna kezy dolgot tezen vala, jelesevl zent eghazhoz valo dolgot, myuet es zenteknek erekleeknek valo ekesse geket..."11

„És elötte valának e szent szüznek minden ö szép aranyos képei, táblái és ereklyéi." 12

„E táblát Szent Margit asszony mindenkoron mind éjjel, mind nappal, mikoron imádkozik vala, szemeinek elötte tartja vala. E táblának elötte leesék Szent Margit asszony és kezeit kiterjesztvén és ismét kezeit összekulcsolván és böséges könnyeket hullatván..."13

„Hagyá elhozni az ö aranyból csinált tábláját, mely táblában vannak nagy sok szenteknek ereklyéjök és az eleven Szent Keresztfa. E táblát Szent Margit asszony mindenkoron mind éjjel, mind nappal, mikoron imádkozik vala, szemeinek elötte tartja vala. E táblának elötte leesék Szent Margit asszony és

\footnotetext{
${ }^{4}$ Az apácamunka szerepe ebben az esetben nem egyszerủen csak a tiszteletből fakadó ékesítés és díszítés, hanem az elrejtés-eltakarás is lehet.

5 Elsősorban a kiváló müvelődéstörténész-pap, Némethy Lajos (+ 1917) Szent Margitra vonatkozó alapos kutatásait követjük.

${ }^{6}$ Bővebben a 2. jegyzetpontban.

${ }^{7}$ Leltári száma: Bazilika Gyarapodási Napló 21/2006.

${ }^{8}$ DEÁK 2005. 273. NÉMETHY 1885. 7. szerint 1271-ben, de ez utóbbi állítás téves, mert 1271. január 18-án, halálának első évfordulóján történt Margit sírjánál az első gyógyulás.

9 Az apácamunkák kutatásánál ez fontos adat.

${ }^{10}$ Érszegi 1983. Dömötör \& Pólya 1990. Király 1979. Klaniczay \& Klaniczay 1994. Klaniczay 2000. DEÁK 2005. 11. DEÁK Viktória Hedvig OP. nagy munkájában Szent Margit és a domonkos hagiográfia kérdéskörét vizsgálta meg. Nyomatékosan kiemeli, hogy nem a történeti Margit-képet kutatja.

${ }^{11}$ DÖMÖTÖR \& PÓLYA 1990. 55.

12 ÉRSZEGI 1983. 133.

${ }^{13}$ ÉRSZEGI 1983. 150.
} 


\section{kezeit kiterjesztvén és ismét kezeit összekulcsolván és böséges könnyeket hullatván..."14}

A tábla nem lehetett más, mint egy olyan házi oltár, amelyet az apácák a cellájukban tartottak. ${ }^{15} \mathrm{Az}$ eleven Szent Keresztfa pedig Szent Kereszt-ereklyét tartalmazó feszület volt, amelyet a Megváltó Krisztus szenvedését különös módon átélő királylány nagy becsben tartott. A házi oltáruk feldíszítését maguk az apácák végezték. Egy másik helyen így ír a legenda:

„Tehát elméne Szent Margit asszony az ő kamrácskájába, az ö imádságainak helyére, aki vagyon az kar között és a köfal között, azaz kit mostan hívunk Szent Margit asszony helyének, mely helyet Szent Margit asszony igen szépen megékesitvén Urunk Jézusnak feszületével és szenteknek képével tartja vala." 16

Az elhunyt királylányt legendái szerint a domonkos kolostor templomának szentélyében, a főoltár elé temették el. ${ }^{17}$ Leírások szerint (Pray-kódex, a Nápolyi Legenda, Guarin) a testénél folyamatosan történtek kisebb-nagyobb csodák. Ezekről még Mátyás király idejéből is bőséges leírásokat találunk. ${ }^{18}$

A fejereklye jelentőségének vizsgálatához külön kiemelendők a Szent Margit-legenda azon elemei, amelyek a hajához ${ }^{19}$ köthető rendkívüli eseményekről számolnak be. A szentkultusz történetében ugyanis a fejereklyék - különösen a könnyen elkülöníthető haj- és fogereklyék - mindig a legértékesebb testi eredetű ereklyéknek számítottak. ${ }^{20}$

A csodás gyógyítások a haj érintésével és olyan víz vagy bor segítségével történtek, amelyekbe a szent haját belemártották. A sírhoz taligán tolt, magatehetetlen asszonyt megszánta

,fráter Vince, ki lakozik vala e klastromnál, ada e betegnek egy foltot Szent Margit asszony skpulárából és az ő szent hajának mosadékvizét és hagyá, hogy e vízzel mosná térdét és a skapulár posztójával törölné; kit eképpen tön a beteg. Ezeknek utána kezdé e beteg magát vonni a földön csúszván. Mikoron e szegény beteg közelítene a koporsóhoz, íme az Úristen, Szent Margit asszonyak érdeme miatt tökéletességgel megvigaszta e szegény beteg asszonyállatot mind a nagy sokaságnak elötte." 21

A huszonhét éves soror Lucia, a veszprémi Uten lánya súlyos beteg lett, öt napig meg sem szólalt, megáldoztatták és megkapta a betegek szentségét.

„Ezeknek utána a szororok megmosták Szent Margit asszonynak haját, és vizét megadák innia. Tehát a beteg szoror legottan szólni kezde, és elméje megjöve és megygógyula.",22

„... szoror Ágnesnek egy időben Szent Iván napján, Szent Margit asszony halála után orcája oly igen megdagada, hogy jobb szemét befedé és nem láthat vala vele. Tehát e szoror vevé Szent Margit asszonynak haját és megtörülé vele az ő orcáját és meggyógyula." 23

\footnotetext{
14 ÉRSZEGI 1983. 150.

15 RÓMER 1868. 19-42. Szent Margit házi oltáráról írt jelentős tanulmányt, amelyben egyúttal jelentős forrásközléseket, leírásokat is találhatunk.

16 ÉRSZEGI 1983. 151.

17 NÉMETHY 1885. 8.

${ }^{18}$ NÉMETHY 1885. 14-17. PÉTERFI 2011. 83-106.

${ }^{19}$ NÉMETHY 1885. 133-136.

20 KlANICZAY 2000. 110. DEÁK 2005. 286. Más domonkos szentekhez köthető, hasonló eljárásokat és gyógyulásokat említ.

${ }^{21}$ ÉRSZEGI 1983. 169-170.

22 ÉRSZEGI 1983. 175.

23 ÉRSZEGI 1983. 176.
} 
Soror Erzsébet, Adorján ispán úr lánya volt.

„... egy időben, Szent Margit asszonynak halála után megmosá Szent Margit asszonynak haját és azt megadá a beteg szorornak innia, mely beteget lelt vala három napig hideg; némikoron negyednapi, némikoron harmadnapi és semmivel meg nem gyógyulhata, hanem csak mosadék borral." 24

Boldog Margit haját a ruháihoz hasonlóan ereklye gyanánt apróbb részletekben szétosztották, amint Somogyi Ágnes apáca esete mutatja, aki arcdaganatát gyógyította meg érintésével:

„,megtevrevle vele ev orchayat es meg gyogyvla”. ${ }^{25}$

Az Árpád-ház szándékának és a csodás gyógyulásoknak is köszönhetö, hogy Margit szentté avatási eljárása már a halála után megindult, de valamiért mindig elakadt. Az életszentsége elismeréseképpen és a sírjánál történt csodák miatt boldognak tisztelték ugyan, ${ }^{26}$ de nem rendelték el teste kihantolását és ereklyeként az oltárra emelését. Ezért teste sokáig a sírjában maradt. ${ }^{27}$ A tisztelet folyamatosságát mutatja azonban, hogy 1409-ben búcsút engedélyeztek mindazoknak, akik a szigeten fekvő zárdában nyugvó boldog Margit testének tiszteletére megjelennek, vagy a zárda vagy a templom építéséhez segítséget nyújtanak. ${ }^{28}$ Feltételezések szerint az elhunytat csak 1510 körül emelték ki onnan, amikor a szigeti templom szentélyét átépítették. ${ }^{29}$ Ezt támasztja alá Ráskai Lea 1510-ben, amikor így fogalmazott Margitnak a szigeti sírjáról:

„kyben mastan es fekzyk ez zent zvz”. ${ }^{30}$

Vagyis akkor még az eredeti helyén nyugodott, tehát testi ereklyéje még háborítatlanul pihent. A testet ezután, 1523 nyarán már ideiglenes helyen látta Kajetán Tamás bíbornok:

„... megmutatták nekünk boldog Margit csontjait”. ${ }^{31}$

A sírból kihantolt csontokat e szerint már ereklyeként tisztelték, hiszen Kajetán a „boldog” jelzőt használta. A feloszlatott klarissza rend 1782-es leltára a Nyulak szigeti apácáktól kapott tárgyak között említ

„egy ezüst ládikát, mely meg van aranyozva és 1512-ben készült. Ebben szokás szent Margitnak fejét nyilvános tiszteletre kitenni" ${ }^{32}$

Ez utal a test felvételére, az ereklyék felosztására ${ }^{33}$ és azok nyilvános tiszteletére. Mindez tehát 1512től kezdve bizonyítható.

A Rituum Congregatio 1542-ben hozott határozata alapján a Domonkos Rend római generálisa intézkedett, hogy január 18-án a rend egyetlen magyarországi zárdájában, Szombathelyen és a magyarországi provinciához tartozó stájer és karintiai kolostorokban is végezzék Boldog Margit officiumát. ${ }^{34}$ Ezek mind Margit életszentségének elismertségét mutatják.

\footnotetext{
${ }^{24}$ ÉRSZEGI 1983. 178.

${ }^{25}$ A Pray-kódexből idézi: NÉMETHY 1885. 136.

${ }^{26}$ NÉMETHY 1885. 21-22. DEÁK 2005. 284. A szentté avatási eljárásnál külön ügyeltek arra, hogy a laikus tanúk nem tévesztik-e össze Antiochiai Szent Margittal, akinek tisztelete miatt volt a Margit keresztnév olyan népszerü.

${ }^{27}$ NÉMETHY 1885. 18.

${ }^{28}$ NÉMETHY 1885. 22.

${ }^{29}$ NÉMETHY 1885. 27.

${ }^{30}$ Dömötör \& Pólya 1990. 251.

${ }^{31}$ NÉMETHY 1885. 31.

32 Idézi NÉMETHY 1885. 32. Az eredeti latin szöveg szerint: „1 Cistula argentea deaurata, opus anni 1512, cuiinponitur pro publico cultu Caput Stae Margarethae.” 464 SU.

33 SoÓs 2006. 5-11.

${ }^{34}$ NÉMETHY 1885. 265.
} 
Árpád-házi Szent Erzsébet után a 13-14. századi Európában ő a legismertebb női szentünk, alakja Itáliában pedig különös jelentőségre tett szert. A domonkos rend legfőbb szentjei között tartották számon. Az ottani szent hagyomány szerint kiválósága elismeréseként stigmákat kapott Istentől. Több ábrázolása így örökítette meg, Trevisoban, Citta di Castelloban, San Gimignanoban. A nápolyi Anjouház, főleg Mária királyné révén a domonkosokra támaszkodva hatékonyan terjesztette tiszteletét. ${ }^{35}$

A történelem eseményei Magyarországon azonban kanyargós mederbe terelték a királylány ereklyéinek és kései oltárra emelésének történetét. A szigeti domonkos apácák 1526-ban, a mohácsi csatavesztés után elmenekültek, de magukkal vitték legdrágább kincseiket, köztük Margit ereklyéit. Rendi hagyományuk 1541-es tavaszi elköltözés legendás emlékét őrizte meg. Eszerint az apácák ládákba csomagolták értékeiket, hogy gyorsabban menekülhessenek a közeledő török seregek elől, de az utazásra bepakolt ládák közül a Boldog Margit ereklyéit tartalmazó ládát a kapkodásban a szigeten felejtették. Már sokat haladtak Nagyvárad felé, amikor Margit jelent meg előttük és így szólt:

„Testvéreim! Miért hagytok engem vissza az ellenség dühének?”

Mire ők visszasiettek, a szent testet magukkal vitték, s ezt az esemény Boldog Margit közbenjárására történt eseménynek tekintették. ${ }^{36}$

Történetileg vizsgálva sok a bizonytalanság. Érthető, hogy végleg elhagyták a szigetet (mintegy negyven föröl lehetett szó), s átmenetileg Nagyvárad mellett telepedtek $\mathrm{le}^{37}$ a szentjánosi bencés apátságban. Itt az elhagyott épületekbe valamikor a mohácsi vész után, de még 1549 elött költöztek be. Innen talán 1556-ban, ${ }^{38}$ de legkésőbb 1564-ben, a még élő 18 nővér Nagyszombatba távozott. ${ }^{39}$

Boldog Margit nagyszombati tiszteletéről nem találtak írásos feljegyzést, de joggal feltételezhetjük a kultusz egykori meglétét. ${ }^{40}$ Az 1768 -as rendtörténet megemlíti, hogy

\section{„... ezen Fehér egy Apáczának gondviseléséért és reá tett költségekért hagytak ezen Nagy-Szombati Klastromban egy ezüst kelhet, egy ezüst keresztet: és egy aranyozottat, egy Vörös igaz gyöngyökkel ezüstel és arannyal kivarrott casulát, kinek a hátán látszik ECCE HOMO ... egy kis gyöngyökkel ki rakott keresztecskét ..." 41}

II. Mátyás 1615-ös rendelete a domonkos nővérek összes vagyonát, ingóságát a klarisszákra ruházta át, így minden ereklye a tulajdonukba került. ${ }^{42}$ Hosszadalmas és méltatlan huzavona után 1618-ban, Pázmány Péter érsek parancsára a domonkos nővérek hagyatékát végleges helyükre költöztették. ${ }^{43}$ Boldog Margit feldíszített ereklyéi és a domonkos nővérek rendkívül értékes könyvei a pozsonyi klarissza kolostorba kerültek, jelentősen növelve a zárda tekintélyét. Pozsony lett Szent Kára, a lengyel születésű Erzsébet királyné ${ }^{44}$ és Boldog Margit tiszteletének központja. A hely sok

\footnotetext{
${ }^{35}$ KLANICZAY \& KlaniCZAy 1994. A San Gimignano-i tisztelet jelentőségét mutatja, hogy Margit ábrázolása a város védőszentjének, Sancta Finának a képe mellett látható. Ezt a helyszínen külön örömmel fedeztük fel. KLANICZAY 2000.

${ }^{36}$ NÉMETHY 1885. 45-46.

${ }^{37}$ NÉMETHY 1885. 49. F. ROMHÁNYI 2000. 16. Jogilag 1541-ig müködött, de az apácák már előbb elköltöztek az üresen álló szentjánosi apátságba.

${ }^{38}$ F. ROMHÁNYI 2000. 90. Nagy a bizonytalanság az említett időhatárokban.

39 NÉMETHY 1885. 60. BUNYITAI 1883-84. II. 501. 1563 őszén még biztosan a szentjánosi apátságban tartózkodtak. F. ROMHÁNYI 2000. 63. A kolostor 1683-ban szünt meg.

${ }^{40}$ NÉMETHY 1885.64.

${ }^{41}$ SCHWARCZ 2002. 189.

${ }^{42}$ NÉMETHY 1885. 77.

${ }^{43}$ NÉMETHY 1885. 71.

44 Erzsébet királyné családi kapcsolatairól, annak dinasztikus jelentőségéről, a szent életü királylányok tiszteletének összefüggéseiről bőven értekezik: KLANICZAY 2000. 34.
} 
külföldi zarándokot is vonzott, a magyar főnemesi családokat pedig a rendház kiemelkedő támogatására ösztönözte. ${ }^{45}$

1635-ben a bécsi egyetem tanára, Sigismundus Ferrarius, a domonkos rend történetírója volt az első, aki Szent Margit ereklyéinek a pozsonyi klarisszáknál való elhelyezéséről írt, ${ }^{46}$ és részletesen beszámolt az általa látottakról. ${ }^{47} 1635$. szeptember 8 -án tekinthette meg az ereklyéket, amelyeket az apácák kórusán őriztek. Mivel az a klauzúra része volt, oda nem mehetett, de a sekrestye ablakán kiadták azokat, s az oltárra helyezték. Ferrarius leírta, amit látott.

$$
\text { „A fej maga és a többi csontok vöröses fekete szinnel birnak." }
$$

Margit fejét Esterházy Miklós nádor felesége, Nyáry Krisztina által készített, latin felírással ellátott gyöngyabroncs övezte. Miklós fiának, a későbbi birodalmi hercegnek, Pál nádornak anyja volt ő:

„,igaz gyöngyökkel ki-rakatott drága koszorút tsináltata, melylyen gyöngyökböl varatott im ez Írás olvastatik Deák nyelven: Boldog Szüz Margitnak, Negyedik Béla Magyar országi Király Leányának feje." ${ }^{49}$

Az eredeti felirat:

\footnotetext{
${ }^{45}$ HORN 1992. 29.

${ }^{46}$ NÉMETHY 1885. 78. A név magyarosított változatát használta: Ferrarius Zsigmond.
}

47 FERRARIUS 1637. 327-329. „Cum mihi anno 1635. pié investiganti de loco sanctissimimarum harum Reliquiarum (nonnullorum enim nostrum fama ferebatur, cas Viennae apud Clarissas quasdam existere) a D. Stephano Sennyei Episcopo Iauriensi, Sz Regni Hungariae Cancellario, indicatu fuisset Posonij afferuari, ingens animum desiderium incendit, illas, quando mihi per studiorum occupationes liceret, primo quoq; tempore visitandi. Iraq; instituta peregrinatione, praemissisq, aliquot precum, jejonorum, consimiliumq; pijs exercitijs? Posonium, octo germanicis milliaribus Vienna distantem Vrbem, septima Septembris die perveni. Vbi a Religiosis Sanctissimi Patris Francisei de Obfer, hospitio beneoule exceprus, P. Guardianum, Sz P. Provincialem, qui tunc aderat, enixius rogauti, vtsacra pignora (cujus caussa illuc veneram) visitandi facerent facultatem; ac denique (licit initio Patre aliqunto dissiciles se preabere viderentur) quod tantopere cupiebam, $\mathbf{S z}$ efflagitabam, R. etiam P. Iacobo Nemethi agente, obtimui. Quare ad horam primam pomeridianam, ipsa die Natali B. Virg. Deiparae, R. P. Rector Collegij Societatis Iesu cum P. Nemethi, ego, sociusq; meus ad Clarissarum templum, juxta praeferiptum, accessimus: quando P. Confessarius Sanctimonialium, vnaque socius illius, sacras Reliquias, fenestella Sacristiae ministratas, paullatim ad summum altare detulerunt. Tum porro solustis mihi ex oculis vberrimis lacrymis, Deo pro tantae Virginis gloria, tantaq; gratia mihi collata, gratis, quas potui maximas, egi: laudes ejusdem S. Virg. mecum feruentius celebraui: meis, confratrumq; delictis coram Deo confessis, veniam per illus merita humillime postulaui, me, Ordinemq; meum in Hungaria extinctum, per illamet ferio commendans: ac deniq; ad ipsas Sanctas Reliquias propius contuedas, ex venerandas, qua potui pietate, spe gaudioq; plenus, ac lacrymis perfusus accessi. Aderat Caput, cui circulus Excellentissimae, ex Illustrissimae D. Christinae, Excellentissimi, ex Illustrissimi D. Nicilai Esterhasy Comiris, ex Principis Palatini Conjugis lectissimae, pietate, ex opera pretiose elaboratus, cum hac inseriptione ex vnionibus confecta, Capvt Beatae Margaritae Virginis, Filiae Belae Quarti, Regis Hungariae. Aderant etiam ossa plurima ex costis, tibijs, hrachijs, alijsq; partibus. Quamquam multa etiam illorum pars defideraretur, quod ij, ad quos spectabar custodia, velminus diligentes pro tanto thesauro, vel plus justo prodigi, nedü liberales olim extiterint. At vero cum caput, tum ossa reliqua, colore subrubro, ex nigricante. Ex vestibus etiam aderat pars integra candidae vestis scapularis, in descensu sensim se in latum porrigentis. Frusta etiam tunicae satis decrita. Frustulu icide panni serici albi florigeri, quod Pater ille Confessarius, ex antiqua tradicione, ajebat esse particulam cappae (quam vocant) five pallij serici nigri coloris, quod (cum illo humatum fuisset sacrum corpus virgineum) immutato colore, candidum miraculose reddicum fuit. Vidi eriam cingulum duorom digitorum latitudinis, quo Virgo Sanctissima ad vivam carnem incingebatur: vidi praeterae partes cilicij, ejus przsertim, quod in modum retis erat intextum, flagellorum etiam, ex virgarum particulus, quibus se Virgo Sancta macerare ex coedere consueverat."

Ferrarius müvének Margitra vonatkozó része, csekély átdolgozással német nyelven is megjelent: Vortreffliches Leben Dér Seelig. Gott-geweiohten Jungfrauen Magaritae Einer Königlichen Tochter Belae desz IV. Königs in Hungarn, hernah Ordens S. Dominici in dem Closter Unser Lieben Frauen auff der so von ihr hero gennanten S. Margareten-Insel. Ausz Glaubwürdigen Scribenten verfasset, und in Druckgegeben. Wien 1689. NÉMETHY 1885. 78-82. Ferrarius szövegéböl fordít.

${ }^{48}$ NÉMETHY 1885. 80.

${ }^{49}$ SZILÁRDFY 1984. A VII. kép magyarázó szövege, de röviden említi a szent ábrázolásait is. 


\section{„CAPVT BEATAE MARGARITAE VIRGINIS FILIAE BELAE QVARTI, REGNIS HVNGARIAE."}

Ferrarius1635-ben megjegyezte, hogy az ereklyék olyan állapotban lehetnek, mint amikor herceg Esterházy Krisztina $(+1732)$ az abroncs alakú diadémot a boldogult koponyájára tetette. ${ }^{51}$ A tudós Ferrarius hiába kért egy kis részt az ereklyéből, a nővérek megtagadták tőle. Amikor egyedül maradt, az ereklyéből apró szeleteket vágott le, s magával vitte. ${ }^{52}$

1641 februárjában Lósy Imre esztergomi érsek személyesen kereste fel a klarissza zárdát. A kóruson felnyittatta a vörös bársony szövettel bevont ládát, amely Szent Margit ereklyéit tartalmazta. Ekkor találta meg a szentté avatásra összegyüjtött középkori bizonyítékokat is. ${ }^{53}$

Az ereklyék nyilvános pozsonyi tiszteletéröl 1643. január 18-i keltezéssel van az első feljegyzésünk. Szent Margit ünnepén ismét kitették a koponyát, s újra indultak a zarándoklatok is. A klarisszák megfestették templomukban Margit két méter magas freskóját (2. kép). Erről a képről a 1718. században számos fa- és rézmetszetet készítettek ${ }^{54}$ a következő felirattal:

„Ezen Dicsöséges Szent Margit Szüznek Szent Feje több Szent Reliquiával együtt tartatik és tiszteltetik a Tiszteletes Klárista Szüzeknél Pozsonyban."

A kép után készült metszetek szerint ez volt Margit legjellegzetesebb ábrázolása. ${ }^{56}$ A freskó a századok alatt sajnos olyan rossz állapotba került, hogy az 1942-es renováláskor nem örizték meg. ${ }^{57}$ A királylány tiszteletét mutatja, hogy Lippai György érsek 1656-ban augsburgi ötvösnél rendelte meg Margit ezüstszobrát. ${ }^{58}$ Később a betegségéből felgyógyult föpap

\section{„háláját kifejezendö 1660-ban Margit szüz ezüst szobrát ajánlotta fel a zárdának”.}

A szoborban Margitnak néhány apró ereklyéjét helyezték el ${ }^{59}$ tehát különleges ereklyetartó-szobor volt. ${ }^{60}$ Ebből az időszakból is számos csoda emléke maradt fenn. Sokan - Lippai Györgyhöz hasonlóan - Szent Margit ${ }^{61}$ közbenjárásának és ereklyéi érintésének tulajdonították súlyos betegségükből való felgyógyulásukat. A templom szentélyében fogadalmi adományok egész sora hirdette Szent Margit közbenjárásának hatékonyságát és a hívek háláját. ${ }^{62}$

A szigetről menekült domonkos apácák a pozsonyi zárdába semmiféle hivatalos okmányt nem hoztak magukkal az ereklyék hitelességéröl. Lehet, hogy ilyen irattal korábban sem rendelkeztek. Ezért különleges jelentőségü Eleonóra császárné 1688-as látogatása. Eleonóra ekkor Margit-ereklyét kapott ajándékba, amelyet nagy örömmel fogadott, de igazolást kért annak a hitelességéről. Ezért

${ }^{50}$ NÉMETHY 1885. 80.

${ }^{51}$ NÉMETHY 1885. 82. Gróf Nyáry Krisztina Thurzó Imre özvegye volt, amikor 1624-ben - alig húszévesen feleségül ment gróf Esterházy Miklóshoz, aki 1625-ben nádor lett. Pál fiuk 1635-ben született. Nyáry Krisztina 1641-ben huny el.

${ }^{52}$ NÉMETHY 1885. 78-82. SZYLLABA 1944. 39-40.

${ }^{53}$ KIRÁLY 1979. 166. DEÁK 2005. 15. Mivel az 1276-os tanúvallomásokat tartalmazó, Rómába küldött eredeti jegyzőkönyvek elvesztek, Lósy Imre a koporsóba helyezett dokumentumok másolatát újra Rómába küldte. Ezért sem meglepő, hogy Margit procedúrája esetében forráshiányos anyaggal rendelkezik a kutatás. DEÁK 2005. 277.

${ }^{54}$ KIRÁLY 1979. 166. SZILÁRDFY 1984.

${ }^{55}$ NÉMETHY 1885. 95

${ }^{56}$ NÉMETHY 1885. 146-147.

${ }^{57}$ KIRÁLY 1979. 193. A Szent Margit-ábrázolásokról: 171-194.

${ }^{58}$ TAKÁCS 1900. 95.

${ }^{59}$ NÉMETHY 1885. 272.

${ }^{60}$ KIRÁLY 1979. 166. A középkori szentek szobrai gyakran ereklyetartók is voltak. Ezt akkor különleges, csodálatos erőnek tulajdonították, ami vonzotta a zarándokokat. SEIBERT 1986. 82.

${ }^{61}$ Árpád-házi Szent Margit tiszteletének elemei összefonódtak Antiochiai Szent Margit tiszteletével. Erröl részletesen: BÁLINT 1977. II. 36-45. ORBÁN 2001. 154-160.

${ }^{62}$ NÉMETHY 1885. 266. 
Széchenyi György esztergomi érsek megbízásából a káptalan két kanonokot küldött ki az eredetiség megállapítására. Ök egybehívták az apácákat, valamint a helybeli jezsuita és a ferences kolostor házfönökeit (ez utóbbi egyben a klarisszák gyóntatója is volt). A nővérek elmondták az ereklyék odakerülésének történetét, s felmutatták Margit házi oltárát, az aranyozott ezüstládikát, illetve az ereklyetartót is, amelyben a szent fejereklyéjét őrizték. Ez utóbbit Bethlen Gábor fejedelem katolizált özvegye, Brandenburgi Katalin készíttette 1634-ben. ${ }^{63}$ A vizsgálatok lezárásaként a hitelesítő okmányt kiadták. ${ }^{64}$

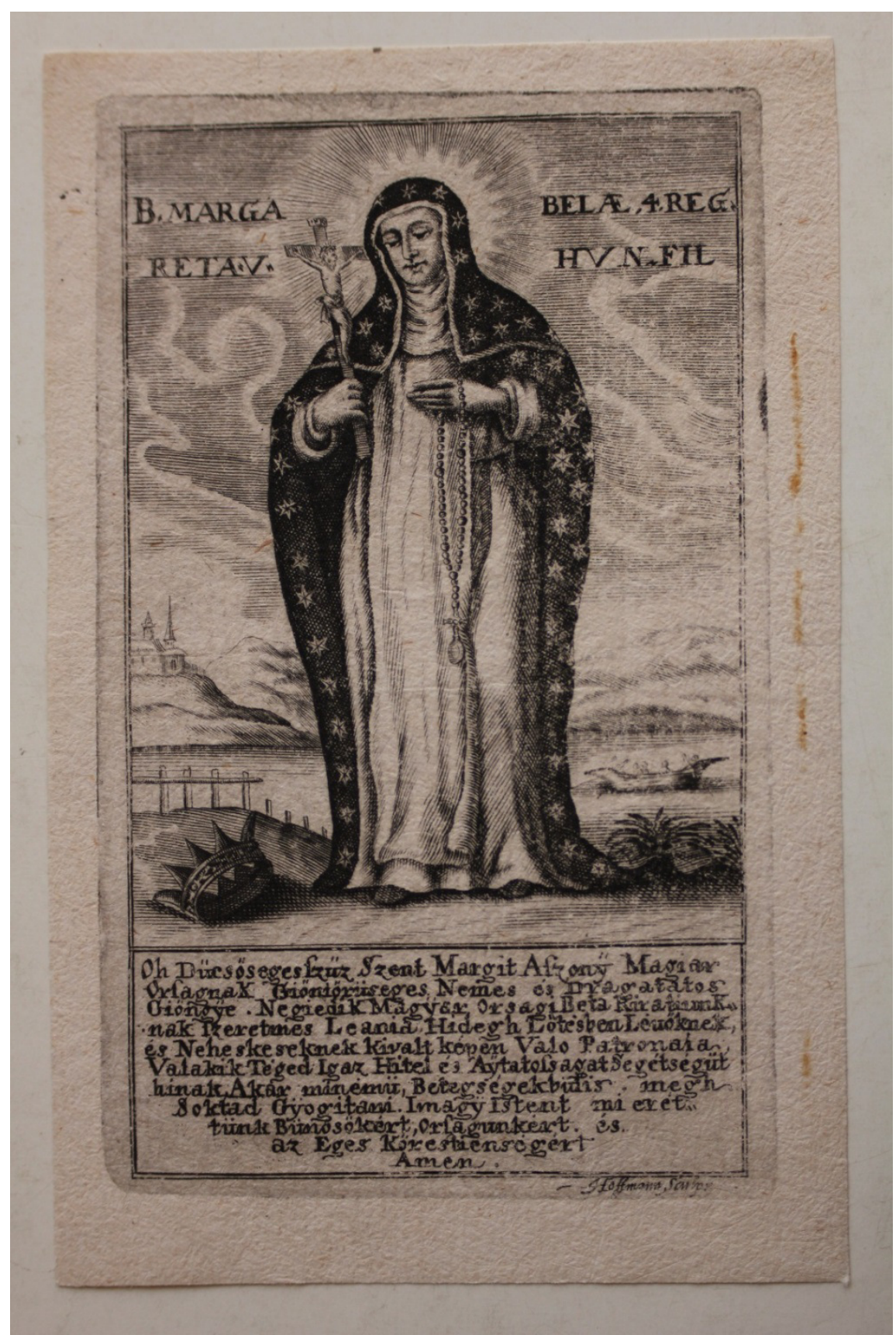

2. kép. Szent Margit. Rézmetszet, papír. Metsző: Hoffmann német mester. Pozsony, 1692 körül. 13,1x8,3 cm. Magántulajdonban.

\footnotetext{
${ }^{63}$ BEKE 1990. 306. Ovális alakú, bársonyos, ezüstös faláda, amelyben nem volt hitelesítő okirat.

${ }^{64}$ SzYLLABA 1944. 42-43. A dokumentum másolata a pozsonyi társaskáptalan irattárában, a 48. számú protocollumban található.
} 
1725-ben a dominikánus rend provinciálisa látogatta meg a zárdát. Külön kiemelte a Rómába küldött jelentésében, hogy a klarisszák bőkezüen osztogatták a királylány ereklyéit. ${ }^{65}$

Egy 1726 augusztusában kiállított irat szerint a klarissza templom két búcsúnapján, Szent Margit halálának napján, január 18-án és július 13-án az ő védőszentjének, Antiochiai Szent Margitnak ünnepén még külföldről is sokan keresik fel a templomot. Ereklyéit körmenetben viszik körül, sőt rendkívüli gyógyulások is előfordulnak (3. kép). ${ }^{66}$

„A domonkosok korábbi gyakorlatát követték a pozsonyi klarisszák, amikor január 18-át körmenettel ünnepelték meg. Ez alkalommal antifonát és imádságot is végeztek a szentnek tiszteletére. Július 13-án pedig ünnepiesen megülték Szent Margit szüz vértanúnak napját is, mert Árpádházi Margit ennek a szentnek a nevét viselte. Ezen a napon a szent királyleánynak virágfüzérekkel díszített fejét az ereklyetartóban köztiszteletre a templom föoltárára helyezték. Az ünnepies misén és vecsernyén a hívö lakosság nagy tömegben jelent meg. Az istentisztelet után az elökelöségnek megengedték, hogy a szent ereklyét csókjukkal illessék. A papok a hívök rózsafüzéreit és egyéb tárgyait az ereklyéhez érintették. Boldogok voltak azok, akik az ereklyét díszítö füzérekböl egy-egy virágot vagy levelet kaphattak."67

A királylány tiszteletének jele volt, hogy a klarisszák úgynevezett „Szent Margit-vizet” készítették. Tiszta vízbe mártották Margit ereklyéit, közben az apácák három Miatyánkot és Üdvözlégyet és egy Hiszekegyet imádkoztak. Ugyanezeket kellett imádkozniuk a betegeknek, miközben a vizet kortyolgatták. Ez a víz főleg lázas betegek esetében bizonyult hatásosnak. ${ }^{68}$ Margit ciliciumát pedig nehéz szüléseknél vették igénybe. ${ }^{69}$ Gyógyító hatást tulajdonítottak ciliciumainak (vezeklő öv), ${ }^{70}$ cordájának (öv), ${ }^{71}$ scapuláréjának $^{72}$ és legföképpen velumának (zárdafátyol) ${ }^{73}$ is. Az 1713-as pusztító pestis tömegesen szedte Pozsonyban is az áldozatait. A lakosság kérésére Szent Margit ereklyéit ünnepélyes körmenetben hordozták körül a városban, mire a ragályos betegség hamar elmúlt. ${ }^{74}$

1749-ben az esztergomi székesegyház kincseiről felvett leltárban a 20. tétel Boldog Margit ereklyéit említi:

„Sz. Margitnak szobra, azelött ereklyék nélkül, most azokkal, melyek legujabban találtattak."

Úgy tünik, hogy az akkor Nagyszombatban tartózkodó esztergomi káptalan a klarissza apácáknak hat aranyat fizetett az ereklyéknek a szokott díszítményekkel való felékesítéséért, ${ }^{75}$ vagyis zárdamunkáért, közismertebb nevén apácamunkáért.

Berchthold Ferenc novi püspök 1770-es állapotfelmérö jelentésében írja a pozsonyi rendházról: „Az apáczák chorusán oltár áll, mely körül van véve csinos képekkel. Ezen öriztetik szent Margit szüznek feje ezüst szekrényben."76

\footnotetext{
${ }^{65}$ NÉMETHY 1885. 270.

${ }^{66}$ KIRÁLY 1979. 168.

${ }^{67}$ NÉMETHY 1885. 266.

${ }^{68}$ NÉMETHY 1885. 266-267. SZYLLABA 1944. 45.

${ }^{69}$ NÉMETHY 1885. 114-117.

${ }^{70}$ NÉMETHY 1885. 114-116. E megjegyzés szerint tehát több darabról lehetett szó.

${ }^{71}$ NÉMETHY 1885. 117-120. 132. TAKÁCS 1982. 335-339.

72 NÉMETHY 1885. 130-131.

${ }^{73}$ NÉMETHY 1885. 126-129.

${ }^{74}$ NÉMETHY 1885. 45-46. 267. KIRÁLY 1979. 167-168.

${ }^{75}$ NÉMETHY 1885. 97. 142-143.
} 
Az 1782-es cassationalis leltár feljegyzése szerint:

„b. Margitnak nagybecsü virágokkal, gyöngyökkel, gyémántokkal és drágakövekkel megrakott ereklyéje, mely a karzaton tartatik. ",77

Az 1768-as rendtörténet felsorolja az egyes kolostorokban őrzött ereklyéket. Pozsonyban:

„Ezen Klastromban illendö Tiszteletben tartatnak némely Szentek Tetemi, ugymint: Sz: Maria Magdolnának Lába Csontya. Szüz Sz: Margitnak néhai Negyedik Bela Király Leányának Feje, és csontjai, annak Ruhájanak egy része, és a Ciliciuma, melynek hasznát tapasztalták sok Gyermek Szülö Asszonyok. Tartatnak itten azon Ersébeth Királnénak Csontyai, aki régenten Ó Budaiai Klastromot fundálta, és épétette: és no ha ezen Sz: életü Asszony á Szentek Lajstromába bé irva nincsen, de Sz: életének neve, és hire máj napig fönt maradott,” 78 Budán: „...melyeket Posonybul hoztak vala tudni illik már emlétett Ersébet Királynénak drága Kövekkel és Gyöngyökkel béfoglalt, ugymint Ó Budai Klastromjoknak nehai Fundatorjéjának Feje. Negyedik Bela Király Leányának, Sz: Margitnak néhai Nyúl Szigeti Sz: Domonkos Szerzetén lévő Apáczának egyik Karja.” 79 „Az apáczák birtokában szintén számos különféle ereklye fordul elö, de mivel sem az nincs feljegyezve, mely ereklyékkel birt b. Margit, de még az sem, hogy egyik vagy másik ereklye azok közül maradt, a melyek egykor b. Margitéi valának, igy meg kell elégednünk azon tudattal, miszerint igen is. B. Margit birt szentek ereklyéivel, melyeket ö maga saját kezemunkájával ékesitett vala." 80

A klarissza rend feloszlatása után a felvilágosodás tovább pusztított. Az 1782-ben lefoglalt és kifosztott ereklyéket a budavári ferences zárdában halmozták fel, s azokat más lefoglalt tárgyakkal együtt 1789 áprilisában egyszerüen elégették. A Pozsonyban leltárba vett és császári parancsra a tűz martalékává vált ereklyék:
„A clarissáktól:
Szent Margitnak a feje. valának." $" 1$
„Szent Erzsébetnek egy ereklyéje.
Néhány ereklye hat piramisból.
Néhány ereklye négy piramisból.
Néhány ereklye két piramisból.

Szent Margitnak egy ereklyéje a pénzverdének átadott szoborból.

Vörös bársonnyal bevont faládika, melyben szent Margit ereklyéi elzárva

\footnotetext{
${ }^{76}$ NÉMETHY 1885. 89. Ferrarius a fejen kívül számos más csontot is említ: bordákat, karokat és lábszárakat. Kósa nagy általánosságban fejet és csontokat, Berchthold pedig már csak fejet említ. Kósa Jenő „Collectanea” címü kézirata az egykori ferences Szűz Mária Tartomány levéltárában volt olvasható. 568. 1.

${ }^{77}$ NÉMETHY 1885.95.

${ }^{78}$ SCHWARCZ 2002. 206.

${ }^{79}$ SCHWARCZ 2002. 210.

${ }^{80}$ NÉMETHY 1885. 106-107.

${ }^{81}$ NÉMETHY 1885. 272. Némethy fordításában.

A kamarai leltár a pozsonyi zárdában talált Margit-ereklyéket három pontban sorolja föl:

a) Reliquien dér heil. Margaretha von einer ans Münzamt abgegebenen Statue.

b) Das Haupt dér heil. Margaretha.

c) Ein hölzernes mit rothem Samm tüberzogenes Trugel worinnen die Reliquien dér heil. Margaretha verschlossen sind. (Ossa 2 maiora ex manu.)
} 
Néhány ereklye két piramisból.
Néhány ereklye két piramisból., ${ }^{, 82}$

Az 1782-ben lefoglalt ereklyékről II. József úgy intézkedett, hogy azokat nem szabad elárverezni, hanem az értékes tartókból kiszedve oda kell adni az azokat kérő egyházi személyeknek vagy szerzetesrendeknek. Ami megmaradt, azt 1789. április 11-én elhamvasztották. A hivatalos lista szerint erre a sorsra jutott Szent Margit koponyája is. ${ }^{83}$

Ezzel kapcsolatban azonban kétkedések egész sora merült fel. 1785-ben (tehát az égetések elött) gróf Batthyány Ignác püspök úgy nyilatkozott, hogy Árpád-házi Margit teste az ö birtokában van. ${ }^{84}$ (1635-ben Ferrarius még egy ládában látta a koponyát, a többi csontokat és egyéb ereklyéket. 1688ban Eleonóra császárné kapott tekintélyes részt a csontokból, amihez - utólagos vizsgálattal hitelesítő iratokat is mellékeltek.) 1782-ben a fejereklyét külön ezüsttartóban őrizték. Ebben az évben Batthyány Franciska klarissza apáca (Batthyány püspök közeli rokona) és három társa kérte a császártól, hogy magukkal vihessék a királylány relikviáit. Erre válasz nem érkezett, a püspök pedig nem kérte az ereklyék átadását. Ennek csak az lehet a magyarázata, hogy azok közvetlenül - a rokona segítségével - hozzá kerültek, amint ezt támasztja alá az 1785-ös nyilatkozata is. Azonban amikor Fraknói Vilmos azt feltételezte, hogy az ereklyék hollétére való kérdésére az erdélyi egyházmegyéből kaphat pontos választ, az a felvilágosítás érkezett számára, hogy Margit ereklyéi sohasem voltak az egyházmegye területén. ${ }^{85}$ 1936-ban báró Jeszenák Gábor pozsonyi prépost-kanonok, pápai prelátus próbálta megkeresni a lehetséges magyarázatot a fenti látszólagos ellentmondás feloldására. Batthyány püspök nyilvánvalóan nem az összes ereklyét birtokolta, hanem csak egy részét. Minden bizonnyal tudhatott arról, hogy az apácák az ereklyék legértékesebb részét elrejtették, ezért nem kérte azok átadását. Lehet, hogy a tulajdonában lévő részek valamelyik családi birtokra kerültek.

A császári biztosok mindenhol megeskették a szerzeteseket, hogy mindent átadnak és semmit sem rejtenek el. A letett esküt azonban annak jogtalanul kierőszakolt volta miatt nem tekintették érvényesnek. Ezért fordulhatott elő a relikviák elrejtése. ${ }^{86}$

„Jeszenák prelátus mindenesetre erösen megalapozta azt a véleményét, hogy a pozsonyi klarisszák befalazták Margit ereklyéit, illetve azoknak egyik részét. Dankó József pozsonyi kömüvesmester 1782. május 12-én kelt pótvégrendeletére hivatkozik, mely szerint a klarisszák apátnője a nevezettet titoktartás kikötése mellett megbízta, hogy a kolostor kriptájában segéd nélkül öt lábnyira azon helytöl, ahol Balassa apátnö hamvai nyugosznak, egy régi fülkét szabaddá tegyen és gondosan megtisztítson. A kömüvesmester ezt meg is tette, mire az apátnő meghagyta neki, hogy április 5-én kömüvesszerszámaival ismét jelentkezzen a kolostorban. Ezen a napon az apátnö a mester szemeláttára ereklyéket, egyházi felszerelési tárgyakat, iratokat és könyveket helyezett a kiürített fülkébe Ezután utasitotta Dankót, hogy a fülkét gondosan falazza be és a helyet vakolókanállal húzott három vonallal jelölje meg. Az apátnö szigorú titoktartást követelt a mestertöl, de azt nem tiltotta meg, hogy az elvégzett munkáról feljegyzéseket tegyen. Kikötötte azonban, hogy ezeket a feljegyzéseket biztonságba helyezi és hogy azoknak száz év leforgása elött nem szabad a nyilvánosság elé kerülniük. Azt is tudtára adta a mesternek, hogy az ekként befalazott ereklyéket és egyéb tárgyakat ajándékul szánta azoknak a katolikus

\footnotetext{
${ }^{82}$ NÉMETHY 1885. 240-247.

${ }^{83}$ SZYLLABA 1944. 58.

${ }^{84}$ SZYLLABA 1944. 59. NÉMETHY 1885. 271.

${ }^{85}$ NÉMETHY 1885. 271-274.

${ }^{86}$ SZYLLABA 1944. 59-64.
} 
egyházi személyeknek, akik a pozsonyi kolostorban a jövőben törvényesen lakni és a templomot használni fogják, - ezt a szándékát egyébként a befalazott iratok és könyvek bizonyitják. Az érdekes végrendelet a pozsonyi városi levéltárban ma is megtalálható." 87

Mivel a nővérek legbecsesebb kincse Szent Margit koponyaereklyéje volt, s ha nem adták oda előzőleg Batthyány püspöknek, biztosan befalaztatták. Csakhogy az épületet azóta 1786-ban, 1812ben, 1850-ben már jelentősen átépítették, s a kripták helyére pincét készítettek. ${ }^{88}$ A munkák elvégzése alatt semmilyen hivatalos feljegyzést nem írtak, amely az elrejtett dokumentumok és ereklyék megtalálását jelezte volna. Dankó kőmüves végrendelete azonban ébren tartja azt a reményt, hogy e fontos nemzeti ereklye valahol lappang.

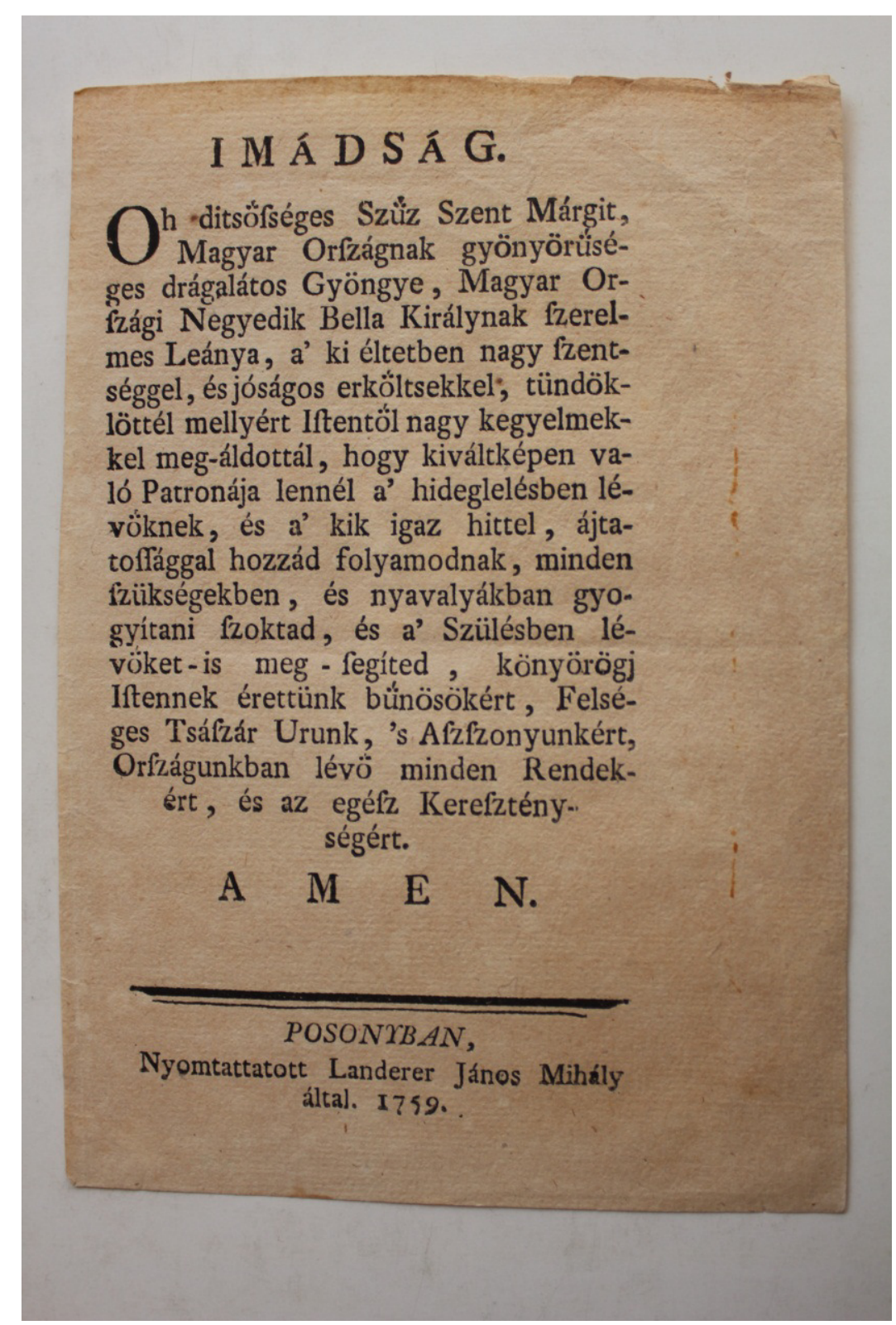

3. kép. Imalap, papír. Pozsony, 1759. 16x11,3 cm.

Nyomtattatott Landerer Mihály által. Magántulajdonban.

\footnotetext{
${ }^{87}$ SZYLLABA 1944. 64-65.

${ }^{88}$ SZYLLABA 1944. 66.
} 
Szyllaba Emil kutatásaival kiegészítette és ellenőrizte Jeszenák Gábor eredményeit. Sajnos az eredeti iratok a II. világháború alatt megsemmisültek, de bizonyos feljegyzésék megmaradtak, amelyek Király Ilonához kerültek. ${ }^{89}$

Csak feltételezhetjük: ha a nővérek mindenáron meg akarták menteni az ereklyét, akkor a Nyáry Krisztina által készített fejdíszbe más koponyát helyeztek, s azt adták át a megsemmisítésre. Tehát könnyen előfordulhatott, hogy 1789-ben az eredeti, mindenki által ismert koronás díszítmény alatt egy másik koponya hamvadt el.

Ebben az esetben a klarisszák gyorsan - lehet, hogy a régi mintájára - új koronát és koponyatakarót készítettek kedves ereklyéjük számára, s azt falazta be a kőműves. A téli kápolnában örzött ereklye díszítési módja, az anyagok, a kivitelezés, a gazdag ékesítés - szakrestaurátori vizsgálat híján - a 18. század vége és a 19. század közepe közötti kivitelezést támaszthatja alá. Mindemellett figyelembe veendő, hogy egy pincében való befalazásnak és hosszabb idejü tárolásnak a koponyatakaró anyagára és a díszítéseire milyen hatása lehet. Lehetséges, hogy amit látunk, az már a harmadik koponyatakaró? Ha igen, kérdés maradhat, mikor készült, ki készíthette, hiszen a rendet feloszlatták. A rendtagok közül azonban egyesek még sokáig éltek. Akárhogy lehetett, a feltételezésnek nincs bizonyító ereje. Erről is vizsgálat szükséges, amely legalább a technikáról, a felhasznált anyagokról és a készítés koráról adhat biztosabb támpontokat. Az azonban tény, hogy egy ereklyének nevezhető koponya (vagy annak nagyobb darabjai), amelyről azt feltételezik, hogy az Szent Margité lehetett, valamikor az esztergomi bíboros szobájába került. A rendház pincéjében 1782-ben elrejtett egyéb tárgyak sorsát azonban továbbra is homály fedi.

A domonkos nővérek által a klarisszákra hagyományozott Szent Margit-ereklyék hitelességét korábban (1688) egyházi vizsgálat tisztázta és elfogadta azok minden kétséget kizáró voltát. Ennek alapja nem hitelesített dokumentumokon és lepecsételt csontdarabkákon nyugodott, hanem azon a tiszteleten, amelyet a domonkos nővérek tanúsítottak legdrágább kincsük iránt. Rendi hagyományuk megőrizte ennek az általuk 1541 tavaszára datált menekülésnek a legendás elemekkel átszőtt emlékét. E hagyomány tiszteletéről és megbízhatóságáról tanúskodik az 1688-as vizsgálat. Ez a tisztelet lehet az esetleges fejereklye hitelességének elméleti bizonyítéka is.

Szükség lesz természettudományos vizsgálatokra, hiszen csak ezek segíthetnek a kormeghatározásban és adhatnak választ a kérdésekre: a koponya és az ismert csontereklyék ${ }^{90}$ egy személytől származnak-e, bizonyítható-e az Árpád-házi rokonság?

Zolnay László hivatkozása szerint

„a különválasztott koponyaereklye pedig máig megvan Pozsonyban. Anélkül hogy az azt örzö egyházi intézmény tudna arról"'11

még teljes joggal megállhatná a helyét, de a lábjegyzetében hozzáteszi

„E felismerésröl - amelyet már két antropológus is hitelesített - dr. Király I., 1979. monografikus müvében olvashatunk.,"92

De erről Király Ilona munkája semmilyen utalást nem tartalmaz. ${ }^{93}$

A Keresztény Múzeum 2000-ben rendezett kiállítást a Magyar szentek tisztelete és ereklyéi címmel. ${ }^{94}$ A kiállítás katalógusában a 13. szám alatt szerepel:

\footnotetext{
${ }^{89}$ KIRÁLY 1979. 170. Ezek sorsáról nincs tudomásom.

90 NÉMETHY 1885. 249-250. Szent Margit csontereklyéi találhatók a győri orsolya apácáknál, Bécsben a Szent István Székesegyházban is. Ezeknek a hitelesített ereklyéknek és a koponyának az összehasonlító vizsgálata alapkérdésekre adhat választ.

91 ZOLNAY 1982. 566.

92 ZOLNAY 1982. 595. KIRÁLY munkájából pontos oldalszám hivatkozást nem közölt.

93 KIRÁLY 1979.
} 


\section{„Szent Margit csontereklyéje." \\ „Valószínüleg Scitovszky János hercegprímás kapta a pozsonyi Erzsébet apácáktól, 1855-ben."}

Az Úrmutató alakú ereklyetartó osztrák munka, 1750 körül készült. Rokokó stílusú, aranyozott ezüst. ${ }^{95}$ Az apró csontereklye a közepén látható. A kiállítás másik ereklyéje Boldog Margit vasöve ${ }^{96}$ amit egy csontdarabkával együtt a klarissza rend feloszlatása után a pozsonyi Erzsébet apácákhoz átment nővérek vitték magukkal. 1855-ben Simor János bíboros hercegprímásnak ajándékozták, aki díszes ereklyetartót készíttetett számára. ${ }^{97}$ Az övtartó 1881-ben Bécsben készültt. ${ }^{98}$

\section{Irodalom - References}

BEKE M., (1990): A budavári klarisszák működése 1714-től 1782-ig. In: Nemes I. (szerk.): Dunántúl településtörténete 8, pp. 305-316. MTA Pécsi és Veszprémi Akadémiai Bizottsága, Pécs és Veszprém.

BAROS GY. (1938): Boldog Margit legendája. Királyi Magyar Egyetemi Nyomda, Budapest.

BUNYITAY V. (1883-84): A váradi püspökség története alapításától a jelenkorig. I-III. Váradi Püspökség, Nagyvárad.

DEÁK V. H. (2005): Árpád-házi Szent Margit és a domonkos hagiográfia. Kairosz, Budapest.

ÉRSZEGI G. (szerk) (1983): Árpád-kori legendák és intelmek. Osiris, Budapest.

FERRARIUS, S. (1637): De rebus Hungaricae provinciae Ordinis Praedicatorum partibus quatuor et octo libris distributi commentarii. Typis Matthaei Formicae, in Aula Coloniensi, Viennae Austriae.

F. RomHÁNYI B. (2000): Kolostorok és társaskáptalanok a középkori Magyarországon. Pytheas, Budapest.

Hoppál M.; Jankovics M.; NAGY Gy. \& SzemedÁm Gy. (1996): Jelképtár. Helikon, Budapest.

HORN I. (1992): Csáky Anna Franciska és a pozsonyi klarisszák. Aetas 8(3): 38-42.

KIRÁly I. (1979): Árpádházi Szent Margit és a sziget. Szent István Társulat, Budapest.

KLANICZAY G. (2000): Az uralkodók szentsége a középkorban. Balassi, Budapest.

KLANICZAY T. \& KLANICZAY G. (1994): Szent Margit legendái és stigmái. Argumentum, Budapest.

CSÉfAlvay P. \& KonTSEK I. (szerk.) (2000): Magyar szentek tisztelete és ereklyéi. Keresztény Múzeum, Esztergom.

NÉMETHY L. (1881): A pozsonyi clarissák leltára. Jegyzéke azon egyházi készleteknek, melyek 1782ik év márczius hó 4-én és következő napokon, az apácza szerzet megszüntetésére alkalmával a császári biztosok által összeirattak. Egyházmüvészeti Lap, 2: 308-314.

NéMETHY L. (1885): Adatok Árpádházi Boldog Margit Történetéhez. Szenttéavatása és cultusára vonatkozólag Fraknói Vilmost-tól. Rudnyánszky Nyomda, Budapest.

Orbán I. (2001): „Ecce, iam vici mundum!” Antiochiai Szent Margit tisztelete Magyarországon. METEM, Budapest.

PÉTERFI B. (2011): Újabb adalékok Árpádházi-Margit középkori csodáinak sorához. In: KÁDÁR Zs.; Mikó G.; PÉTERFI B. \& VADAS A. (szerk.): Micae Mediaevales. Tanulmányok a középkori

\footnotetext{
${ }^{94}$ MAGYAR SZENTEK TISZTELETE ÉS EREKLYÉI. Rendezte: Cséfalvay Pál és Kontsek Ildikó (CSÉFALVAY \& KONTSEK 2000.)

${ }^{95}$ CsÉFALVAY \& KonTSEK 2000. A 114. és 13. számú tárgyakról van szó. Az 1688-as hitelesítés után ezt Margit ereklyéjének kell tartanunk.

${ }^{96}$ CSÉFALVAY \& KONTSEK 2000. 113. 12. számú tárgy.

${ }^{97}$ KIRÁLY 1979. 169.

${ }^{98}$ CSÉFAlvay \& KontSeK 2000. 113.
} 
Magyarországról és Európáról, pp. 83-106. ELTE BTK Történelemtudományok Doktori Iskola, Budapest.

RÓMER F. (1868): Szent Margit házi oltára. Archelogiai Közlemények, Új folyam 5(2): 19-42.

SCHWARCZ K. (2002): „,Mert ihon jönn Assonyotok és kezében uj szoknyák”. Források a klarissza rend magyarországi történetéböl. Budapesti Történeti Múzeum, Magyar Egyháztörténeti Enciklopédiai Munkaközösség, Budapest.

SEIBERT J. (szerk.) (1986): A keresztény müvészet lexikona. Corvina, Budapest.

Soós S. (2006): Apácamunkák. Keresztény Múzeum, Esztergom.

DÖMÖTÖR A. \& PÓLYA K. (1990): Szent Margit élete 1510. MTA Nyelvtudományi Intézet, Budapest.

SZILÁRDFY Z. (1984): Barokk szentképek Magyarországon. Corvina, Budapest.

SZYLlABA E. (1944): A pozsonyi klarissza-templom története. Litera, Bratislava.

PÁL J. \& ÚJVÁRI E. (szerk) (1997): Szimbólumtár. Balassi, Budapest.

TAKÁCS S. (1900): Augsburgi ötvösök munkái törökök és magyarok részére. Archeologiai Értesítö, 20: 93-96.

TAKÁCS S. (1914): Régi magyar nagyasszonyok. „Élet” irodalmi és nyomda részvénytársaság, Budapest.

ZolNAY L. (1982): Az elátkozott Buda. Buda aranykora. Magvető, Budapest. 